\title{
Correction to: Introduction to Drones and Technology Applied to the Creative Industry. AiRT Project: An Overview of the Main Results and Actions
}

Virginia Santamarina-Campos and Marival Segarra-Oña

\section{Correction to:}

\section{Chapter 1 in: V. Santamarina-Campos, M. Segarra-Oña} (eds.), Drones and the Creative Industry, https://doi.org/10.1007/978-3-319-95261-1_1

The original version of first chapter was inadvertently published without including the following funder information: "Program for the promotion of scientific research, technological development and innovation of the Counsel of Education, Research, Culture and Sport, Valencian Region. Reference: AORG/2018/093”. The chapter has been updated. 